\title{
Influence of Organic Manures on Plant Height and Dry Matter Production in Wheat (Triticum aestivum L.)
}

\author{
Ch. Siva Naga Lakshmi ${ }^{1}$, Narendra Singh ${ }^{2}$, Gajendra Singh ${ }^{1}$, \\ Ankush Singh ${ }^{1}$ and Pragya Rawat ${ }^{3}$
}

${ }^{1}$ Department of Agronomy, ${ }^{2}$ Department of Veterinary Sciences, ${ }^{3}$ Department of Biotechnology, Alpine Institute of Technology, Premnagar, Dehradun (U.K), India

*Corresponding author

\section{Keywords}

Organic manures, Plant height, Dry matter production, Wheat

Article Info

Accepted:

05 February 2020

Available Online:

10 March 2020

\section{A B S T R A C T}

Wheat is the world's most widely cultivated food crop, wheat is the important leading cereal crops which ranks first among world food crops, measured either by cultivated area 220.41 million ha or by the production $690.86 \mathrm{mt}$ (National Agricultural Statistics Service 2015-2016). The experiment consisted of nine treatments $\mathrm{T}_{1}$ : RDF, $\mathrm{T}_{2}$ : EC (1/4) basal + PM (3/4) basal, T $:$ FYM (1/4) basal + VC (3/4) basal, T : FYM (1/4) basal + PM (3/4) basal, T5: EC (1/4) basal + VC (3/4) basal, T6: FYM (1/4) basal + PM (3/4) top dressing 30DAS, T 7 : EC (1/4) basal + VC (3/4) top dressing (a) $30 \mathrm{DAS}, \mathrm{T}_{8}$ : EC (1/4) basal + PM (3/4) top dressing at 30DAS, T: Control. The study revealed that, among the treatments, $\mathrm{T}_{8}$ recorded highest plant height at 30, 60, 90 DAS and at harvest $(11.53 \mathrm{~cm}, 37.99 \mathrm{~cm} 64.49 \mathrm{~cm}$ and 80.94) respectively, total dry matter at 30,60, 70DAS and at harvest $(25.35 \mathrm{~g}, 90.09 \mathrm{~g}, 128.52 \mathrm{~g}$, and $203.78 \mathrm{~g})$ respectively.

\section{Introduction}

Wheat is highly nutritious cereal foodstuff and its amino acid yield per acre far exceeds that of animal products (Nahm, 2005). In India, wheat is the second most important cereal crop next to rice and a key crop of the green revolution and post green revolution era (Billore, 2009). India stands second among wheat producing countries with respect to area and production. During the crop year 2015-2016, wheat was grown over an area of 30.23 million ha with production of 93.50 million $\mathrm{t}$ with an average productivity of $3.9 \mathrm{t}$ ha $^{-1}$ (Agricultural statistics 2015-2016). In Uttarakhand, wheat is grown over an area of 0.34 million ha with a production of 0.76 million $\mathrm{t}$ and with an average productivity of $2.2 \mathrm{t} \mathrm{ha}^{-1}$ (Agricultural statistics 2015-2016) which is much lower than national average. 
Wheat plays an important role in the cropping programme of Uttarakhand and has already been proved to be the best.

\section{Materials and Methods}

\section{Plant samplings and plant dry weight}

Plant samples were collected at tiller initiation, 30 DAS, 60 DAS, anthesis (70 DAS) and at harvest stages to determine the total dry matter production. Plant samples were collected from second row on either side of the plot to a row length of one matter each time.

After sampling, the plants were separated and were oven dried at $70^{\circ} \mathrm{C}$ to a constant weight to determine the total dry matter. The data was expressed on $\mathrm{m}^{-1}$ row basis in grams $(\mathrm{g})$.

\section{Plant height (cm)}

Five plants will be tagged at random from each plot for recording plant height at various stages. The height will be measured from ground surface to base of the fully opened leaf before the ear emergence and up to the base of ear head after heading.

\section{Number of tillers plant ${ }^{-1}$}

Number of tillers per metre row length from three places (marked with stick) from each plot will be counted at 60 DAS and at harvest.

\section{Experimental details}

\section{Seed source}

For the present study, seeds of wheat variety PBW-550 were obtained from Dept. of agriculture Dehradun, Uttarkhand.

\section{Description of variety}

The wheat variety PBW 550 is a yellow rust resistant version of PBW 550. Its average plant height is $86 \mathrm{~cm}$ and matures in about 145 days. Its average grain yield is 23.0 quintals per acre. It is resistant to yellow and brown rusts and susceptible to loose smut.

\section{Design and layout}

The experiment will be laid out in a Randomized block design (RBD) with three replications. The experimental details and lay out plan are given below:
Crop : Wheat (Triticum aestivum L.).
Variety : PBW-550
Spacing : $22.5 \mathrm{~cm} \times 10 \mathrm{~cm}$
Design : Randomized block design (RBD)
Replications 03
Total treatments : 09
Gross plot $: 2.5 \mathrm{~m} \times 1.5 \mathrm{~m}$
Irrigation channel $: 0.5 \mathrm{~m}$

\section{Treatment details}
$\mathbf{T}_{\mathbf{1}}-\mathrm{RDF}$
$\mathbf{T}_{\mathbf{2}}-\mathrm{EC}(1 / 4)$ basal + PM (3/4) basal
$\mathbf{T}_{\mathbf{3}^{-}}$FYM (1/4) basal + VC (3/4) basal
$\mathbf{T}_{\mathbf{4}}$ - FYM (1/4) basal + PM (3/4) basal
$\mathbf{T}_{5}-\mathrm{EC}(1 / 4)$ basal + VC (3/4) basal
$\mathbf{T}_{\mathbf{6}}$ - FYM (1/4) basal + PM (3/4) top dressing 30DAS
$\mathbf{T}_{7}$ - EC (1/4) basal + VC (3/4) top dressing @ 30 DAS
T $\mathbf{8}$ - EC (1/4) basal + PM (3/4) top dressing at 30DAS
T9 - Control

Note 1: All organics are made equivalent to recommended dose of nitrogen (RDN)

Note 2: FYM: Farm yard manure, VC: Vermicompost, PM: Poultry manure, EC: Enriched compost

Note 3: RDF (recommended dose of fertilizers 100:75:50 $\mathrm{kg} \mathrm{NPK} \mathrm{ha}^{-1}$ )

\section{Cultural practices}

Field was ploughed twice before the 
application of pre-sowing irrigation. After application of pre-sowing irrigation, two harrowing each followed by planking, were given to prepare a fine and compact seed bed with sufficient amount of moisture at the seeding depth. The recommended dose of fertilizer as basal dose was applied.

\section{Manuring and fertilizer application}

Manures like FYM, enriched compost, poultry manure and vermicompost were applied based on the nitrogen content present in them. Quantity of organic manure required for each plot was calculated as per treatments and applied uniformly in the seed furrows opened. Poultry manure and vermicompost were separately used as a basal and as top dressing at 30 days after sowing (DAS) by incorporating in small furrows opened by the side of crop rows. FYM and enriched compost were applied as basal in respective treatments.

Recommended dose of NPK fertilizers for irrigated wheat is 100:75:50 kg/ha-1 respectively. The entire dose of phosphorous and potassium was applied as basal dose through single super phosphate and muriate of potash. Nitrogen was applied as per the treatments in two equal splits viz., at basal and at 30 days after sowing (DAS) through urea in RDF.

\section{Sowing of seed}

The seeds of wheat were sown in the field on $16^{\text {th }}$ November 2017. The seeds were sown directly into the plots made on main field. Sowing was done in row spaced $22.5 \mathrm{~cm}$ later seeds were covered manually. Soon after sowing the plots were irrigated and then regular irrigations were applied at an interval of 10 days.

\section{Inter cultural operations}

Inter cultural practices were done uniformly for all treatments. Thinning was done after 25days of sowing. Weeding was done as and when necessary.

\section{After care and plant protection}

The experimental plots were kept free of weeds by regular hand weeding. Depending upon soil and climatic conditions, protective irrigation was given during the cropping period and need based plant protection measures were taken as and when required.

\section{Harvesting and threshing}

Crop was harvested on $10^{\text {th }}$ April 2018 after attaining physiological maturity. The harvested crop was dried in the sun and weighed before threshing. Each plot was threshed separately as per treatment and the weight of grains per plot was recorded in $\mathrm{kg}$.

\section{Results and Discussion}

The results of experiment conducted to study the effect of organic manures on growth, yield and grain quality of wheat (Triticum aestivum L.) during Rabi season 2018-2019 are presented in this paper.

\section{Growth parameters}

\section{Plant height}

Data on plant height $(\mathrm{cm})$ was recorded at various treatments. Crop growth is presented in Table no. 1 and depicted in Fig: 2

The plant height at 30 DAS did not differ significantly among the treatments. Treatments differed significantly among the treatments at $90 \mathrm{DAS}$ and at harvest. $\mathrm{T}_{8^{-}} \mathrm{EC}$ (1/4) basal + PM (3/4) top dressing @ 30 DAS (64.49 $\mathrm{cm}$ and $80.94 \mathrm{~cm}$ respectively) recorded the tallest plants and was on par with $\mathrm{T}_{6^{-}}$FYM (1/4) basal + PM (3/4)top dressing @ 30 DAS $(64.27 \mathrm{~cm}$, and $80.15 \mathrm{~cm}$ 
respectively), $\mathrm{T}_{2}$ - EC (1/4) basal + PM (3/4) basal $(62.69 \mathrm{~cm}$ and $80.00 \mathrm{~cm}$ respectively) the minimum plant height was recorded under $\mathrm{T}_{9}$ - Control $(60.85$ and $69.75 \mathrm{~cm})$.

Table.1 Plant height $(\mathrm{cm})$ at various growth stages as influenced by organic manures

\begin{tabular}{|c|c|c|c|c|}
\hline \multirow[b]{2}{*}{ Treatment } & \multicolumn{4}{|c|}{ plant height (cm) } \\
\hline & $\begin{array}{c}\text { 30 } \\
\text { DAS }\end{array}$ & $\begin{array}{c}\text { 60 } \\
\text { DAS }\end{array}$ & $\begin{array}{c}90 \\
\text { DAS }\end{array}$ & $\begin{array}{c}\text { At } \\
\text { harvest }\end{array}$ \\
\hline $\mathrm{T}_{1}$ - RDF & 11.05 & 36.69 & 62.23 & 79.10 \\
\hline$T_{2}-\operatorname{EC~}(1 / 4)$ basal + PM (3/4) basal & 11.17 & 37.05 & 62.69 & 80.00 \\
\hline$T_{3^{-}}$FYM (1/4) basal + VC (3/4) basal & 10.50 & 34.99 & 61.30 & 74.17 \\
\hline $\mathrm{T}_{4}$ - FYM (1/4) basal + PM (3/4) basal & 10.92 & 36.11 & 62.38 & 77.41 \\
\hline $\mathrm{T}_{5}-\mathrm{EC}(1 / 4)$ basal + VC (3/4) basal & 10.59 & 35.53 & 61.52 & 76.29 \\
\hline $\begin{array}{l}\text { T6- FYM (1/4) basal + PM (3/4)top dressing @ } \\
\text { 30 DAS }\end{array}$ & 11.41 & 37.77 & 64.27 & 80.15 \\
\hline $\begin{array}{l}T_{7-} \text { EC }(1 / 4) \text { basal + VC (3/4) top dressing @ } 30 \\
\text { DAS }\end{array}$ & 10.71 & 35.65 & 61.86 & 76.23 \\
\hline 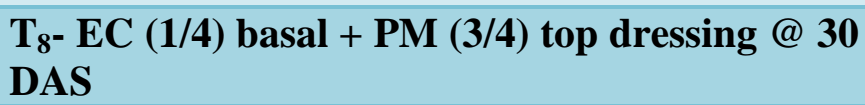 & 11.53 & 37.99 & 64.49 & 80.94 \\
\hline $\mathbf{T}_{9}-$ Control & 10.34 & 34.79 & 60.85 & 69.75 \\
\hline $\mathrm{CD}(\mathrm{p}=0.0$ & 0.095 & 0.311 & 0.675 & 0.960 \\
\hline C.V. & 0.499 & 0.491 & 0.619 & 0.713 \\
\hline S.Em \pm & 0.031 & 0.103 & 0.223 & 0.317 \\
\hline
\end{tabular}

Table.2 Total dry matter production (g) per plant at various growth stages as Influenced by organics

\begin{tabular}{|c|c|c|c|c|}
\hline \multirow[b]{2}{*}{ Treatments } & \multicolumn{4}{|c|}{ Dry matter per plant } \\
\hline & $\begin{array}{c}\text { 30 } \\
\text { DAS }\end{array}$ & $\begin{array}{c}60 \\
\text { DAS }\end{array}$ & $\begin{array}{c}70 \\
\text { DAS }\end{array}$ & $\begin{array}{c}\text { At } \\
\text { harvest }\end{array}$ \\
\hline $\mathbf{T}_{1}$ - RDF & 20.95 & 84.08 & 121.08 & 188.69 \\
\hline$T_{2}$ - EC (1/4) basal + PM (3/4) basal & 22.03 & 85.59 & 123.12 & 190.96 \\
\hline$T_{3^{-}}$FYM (1/4) basal + VC (3/4) basal & 18.80 & 78.05 & 110.16 & 172.02 \\
\hline $\mathrm{T}_{4}$ - FYM (1/4) basal + PM (3/4) basal & 20.74 & 82.75 & 120.36 & 184.95 \\
\hline $\mathrm{T}_{5^{-}} \mathrm{EC} \mathrm{(1/4)} \mathrm{basal} \mathrm{+} \mathrm{VC} \mathrm{(3/4)} \mathrm{basal}$ & 19.39 & 79.80 & 110.50 & 174.02 \\
\hline 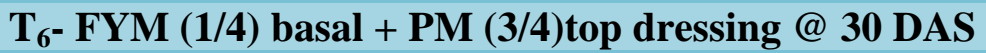 & 24.90 & 86.20 & 126.65 & 201.53 \\
\hline$T_{7}-$ EC (1/4) basal + VC (3/4) top dressing @ 30 DAS & 19.80 & 81.11 & 116.09 & 175.18 \\
\hline $\mathrm{T}_{8^{-}}$EC (1/4) basal + PM (3/4) top dressing @ $30 \mathrm{DAS}$ & 25.35 & 90.09 & 128.52 & 203.78 \\
\hline$T_{9}-$ Control & 17.78 & 76.82 & 108.40 & 167.86 \\
\hline $\mathrm{CD}(\mathrm{p}=\mathbf{0 . 0 5})$ & 0.589 & 1.144 & 1.151 & 1.431 \\
\hline C.V. & 1.601 & 0.792 & 0.557 & 0.445 \\
\hline S.Em \pm & 0.195 & 0.378 & 0.381 & 0.669 \\
\hline
\end{tabular}


Figure.1 Plan layout of the experimental site

\begin{tabular}{|c|c|c|}
\hline $\mathbf{T}_{7}$ & $\mathbf{T}_{5}$ & $\mathbf{T}_{6}$ \\
\hline $\mathbf{T}_{8}$ & $\mathbf{T}_{\mathbf{2}}$ & $\mathbf{T}_{9}$ \\
\hline $\mathbf{T}_{9}$ & $\mathbf{T}_{\mathbf{3}}$ & $\mathbf{T}_{8}$ \\
\hline $\mathbf{T}_{6}$ & $\mathbf{T}_{4}$ & $\mathbf{T}_{7}$ \\
\hline $\mathbf{T}_{\mathbf{3}}$ & $\mathbf{T}_{1}$ & $\mathbf{T}_{4}$ \\
\hline $\mathbf{T}_{4}$ & $\mathbf{T}_{6}$ & $\mathbf{T}_{\mathbf{5}}$ \\
\hline $\mathbf{T}_{5}$ & $\mathbf{T}_{7}$ & $\mathbf{T}_{2}$ \\
\hline $\mathbf{T}_{2}$ & $\mathbf{T}_{8}$ & $\mathbf{T}_{1}$ \\
\hline $\mathbf{T}_{1}$ & $\mathbf{T}_{9}$ & $\mathbf{T}_{\mathbf{3}}$ \\
\hline
\end{tabular}


Fig.2 Plant height $(\mathrm{cm})$ at various growth stages as influenced by organic manures

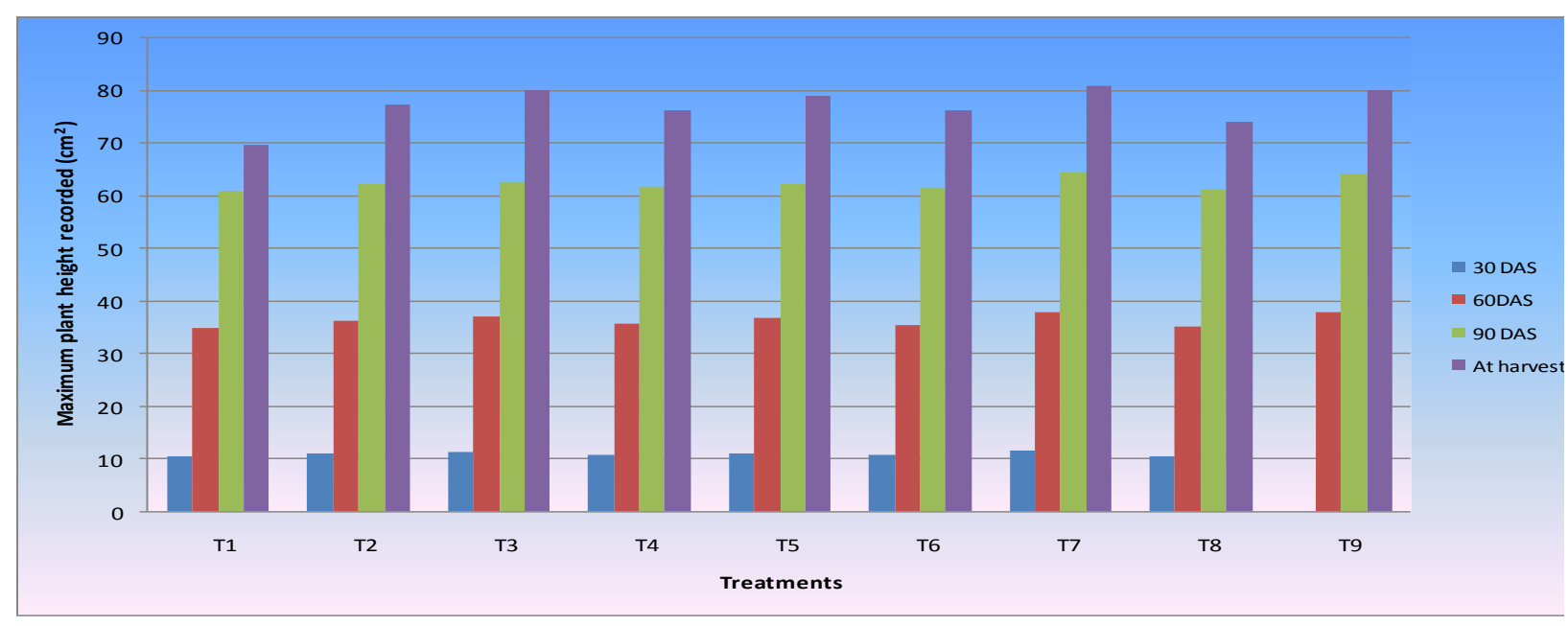

Fig.3 Total dry matter production (g) per plant at various growth stages as Influenced by organics

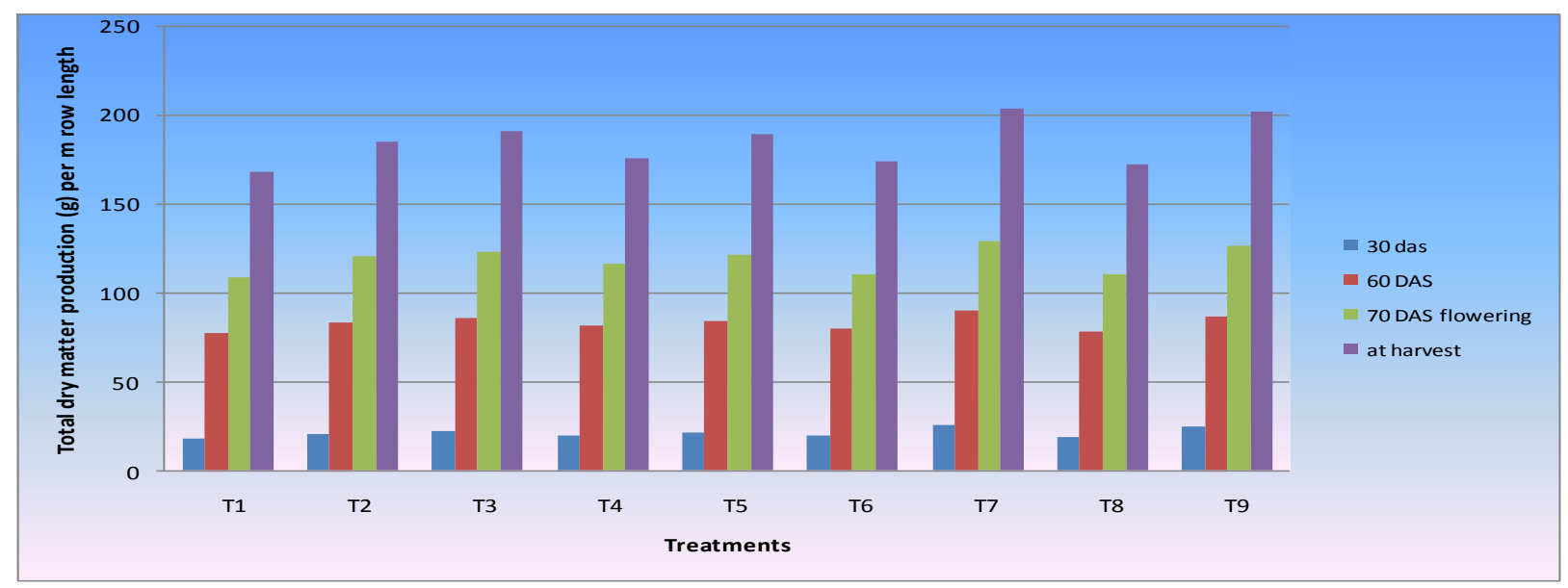




\section{Total dry matter (g) per plant}

Data In respect of periodical accumulation of mean total dry matter plant ${ }^{-1}(\mathrm{~g})$ as affected by various treatments are presented in Table no. 2 and depicted in Fig: 3

The total dry matter produced per plant significantly highest among the treatments at $30,60,70 \mathrm{DAS}$ and at harvest, respectively in $\mathrm{T}_{8}$ - EC (1/4) basal + PM (3/4) top dressing @ 30 DAS $(25.35,90.09,128.52$ and $203.78 \mathrm{~g}$ respectively) recorded was on par with $\mathrm{T}_{6^{-}}$ FYM (1/4) basal + PM (3/4) top dressing @ 30 DAS $(24.90,86.20,126.65,201.53 \mathrm{~g}$ respectively), $\mathrm{T}_{2}$ - EC (1/4) basal + PM (3/4) basal $(22.03,85.59,123.12$ and $190.94 \mathrm{~g}$ respectively), the minimum plant height was recorded under $\mathrm{T}_{9^{-}}$Control (17.78, 76.82, 108.40 and $167.86 \mathrm{~g}$ ).

Summary and conclusion of the study are as follows:

Among the growth parameters the plant height had a closer influence on the grain yield which differed significantly at both 60 DAS and harvest.

The plant height at 30 DAS did not differ significantly among the treatments. The treatments differed significantly among the treatments at 90 DAS and harvest. $\mathrm{T}_{8}-\mathrm{EC}$ (1/4) basal + PM (3/4) top dressing @ 30 DAS (64.49 $\mathrm{cm}$ and $80.94 \mathrm{~cm}$, respectively) recorded the tallest plants and was on par with $\mathrm{T}_{6^{-}}$FYM (1/4) basal + PM (3/4) top dressing @ 30 DAS $(64.27 \mathrm{~cm}$, and 80.15 respectively), $\mathrm{T}_{2}$ - $\mathrm{EC}$ (1/4) basal + $\mathrm{PM}(3 / 4)$ basal $(62.69 \mathrm{~cm}$ and $80.00 \mathrm{~cm}$ respectively) the minimum was recorded under $\mathrm{T}_{9}$ - Control (60.85 and 69.75).

The total dry matter produced per plant significantly highest among the treatments at $30,60,70 \mathrm{DAS}$ and at harvest, respectively in $\mathrm{T}_{8}$ - EC (1/4) basal + PM (3/4) top dressing @ 30 DAS $(25.35,90.09,128.52 \& 203.78 \mathrm{~g}$ respectively) recorded was on par with $\mathrm{T}_{6^{-}}$ FYM (1/4) basal + PM (3/4) top dressing @ 30 DAS $(24.90,86.20,126.65 \& 201.53 \mathrm{~g}$ respectively), $\mathrm{T}_{2}$ - EC (1/4) basal + PM (3/4) basal $(22.03,85.59,123.12 \& 190.96 \mathrm{~g}$ respectively). The minimum was recorded under $\mathrm{T}_{9}$ - Control $(17.78,76.82,108.40 \&$ $167.86 \mathrm{~g})$.

\section{References}

Billore. S. D., Joshi O. P., Ramesh. A and Vyas. A. K., (2009) Enhancing wheat production through tillage and integrated nutrient management. Indian Journal of Agriculture Fertilizer, 5 (11): 25-27.

Chandrakumar (2000). Influence of organics, macro, micronutrients and methods of application on yield and yield attributes of wheat under irrigation M. Sc. Thesis, Acharya N. G. Ranga Agricultural University, Rajendranagar, Hyderabad.

Nahm, K. H., (2005). Factors influencing nitrogen mineralization during poultry litter composting and calculations for available nitrogen. World Poultry. Sciences Journal., 61: 238-235.

\section{How to cite this article:}

Ch. Siva Naga Lakshmi, Narendra Singh, Gajendra Singh, Ankush Singh and Pragya Rawat. 2020. Influence of Organic Manures on Plant Height and Dry Matter Production in Wheat (Triticum aestivum L.). Int.J.Curr.Microbiol.App.Sci. 9(03): 1279-1285. doi: https://doi.org/10.20546/ijcmas.2020.903.148 